\title{
Effect of Water Repellents on Hygroscopicity and Dimensional Stability of Densified Fir and Aspen Woods
}

\section{Utjecaj vodoodbojnih sredstava na higroskopnost i dimenzijsku stabilnost ugušćenog drva jele i drva jasike}

\author{
Original scientific paper • Izvorni znanstveni rad \\ Received-prispjelo: 10. 1. 2019. \\ Accepted-prihvaćeno: 20. 11. 2019. \\ UDK: $630 * 812.222 ; 630 * 812.23 ; 630 * 827.4$ \\ https://doi.org/10.5552/drvind.2020.1901
}

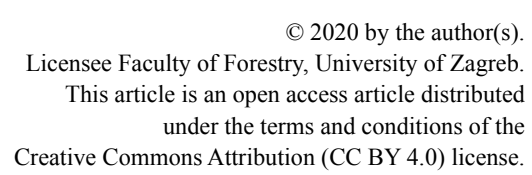

\begin{abstract}
This study investigated the effect of pre-impregnation with water-repellent agents on the hygroscopicity and dimensional stability of fir (Abies bornmulleriana Mattf.) and aspen (Populus tremula L.) woods. After pre-vacuum treatment, the samples were impregnated at atmospheric pressure with paraffin, linseed oil and styrene, and then densified at compression rates of $20 \%$ and $40 \%$ at 120,150 and $180{ }^{\circ} \mathrm{C}$. The results showed that water repellents significantly affected the hygroscopicity and dimensional stability of the densified wood samples. Compression recovery rate (CRR), thickness swelling (TS), equilibrium moisture content (EMC), and water absorption (WA) values of the densified samples decreased with impregnation pretreatments. The linseed oil treatment gave more positive CRR and TS results than paraffin. Lower EMC and WA values were found in the paraffin-treated samples. However, the most successful results for all tested properties were determined in the styrene pretreated samples in which hygroscopicity decreased and dimensional stability increased (especially for aspen) due to increases in the compression rate and temperature related to densification conditions. In the styrene pretreated samples, the high temperature $\left(180^{\circ} \mathrm{C}\right)$ and compression rate $(40 \%)$ significantly reduced $C R R, T S, E M C$ and WA, total dimensional stability was nearly achieved and the water repellent effectiveness was close to $100 \%$.
\end{abstract}

Keywords: densification; dimensional stability; hygroscopicity; impregnation; water repellents

SAŽETAK • U radu se prikazuje istraživanje utjecaja predimpregnacije drva jele (Abies bornmulleriana Mattf.) i jasike (Populus tremula L.) vodoodbojnim sredstvima na njihovu higroskopnost i dimenzijsku stabilnost. Nakon vakuumske obrade uzorci su pri atmosferskom tlaku impregnirani parafinom, lanenim uljem i stirenom. Zatim je provedeno ugušćivanje sa stupnjevima ugušćenja 20 i $40 \%$ pri temperaturi od 120,150 i $180{ }^{\circ} \mathrm{C}$. Rezultati su pokazali da vodoodbojna sredstva značajno utječu na higroskopnost i dimenzijsku stabilnost uzoraka ugušćenog drva. Predimpregnacijom uzoraka smanjili su se stupanj povrata ugušćenja (CRR), debljinsko bubrenje (TS), ravnotežni sadržaj vode (EMC) i apsorpcija vode (WA) ugušćenih uzoraka. Postupkom s lanenim uljem smanjeni

\footnotetext{
${ }^{1}$ Author is associate professor at Faculty of Technology, Duzce University, Department of Wood Products Industrial Engineering, Duzce, Turkey.

${ }^{2}$ Author is M. Sc. at Faculty of Technology, Duzce University, Department of Wood Products Industrial Engineering, Duzce, Turkey.
} 
su povrat ugušćenja i debljinsko bubrenje u usporedbi s postupkom impregnacije parafinom. Na uzorcima impregniranim parafinom utvrđene su niže vrijednosti ravnotežnog sadržaja vode i apsorpcije vode. Međutim, najbolji rezultati svih istraživanih svojstava dobiveni su na uzorcima impregniranima stirenom, kojima se zbog povećanja brzine i temperature ugušcivanja smanjila higroskopnost i povećala dimenzijska stabilnost (posebice drva jasike). Na uzorcima impregniranima stirenom i ugušćenima pri temperaturi od $180{ }^{\circ} \mathrm{C}$ sa stupnjem ugušćenja $40 \%$ znatno su se smanjili stupanj povrata ugušćenja, debljinsko bubrenje, ravnotežni sadržaj vode i apsorpcija vode te je postignuta gotovo potpuna dimenzijska stabilnost i učinkovitost odbijanja vode (blizu $100 \%$ ).

Ključne riječi: ugušćivanje; dimenzijska stabilnost; higroskopnost; impregnacija; vodoodbojna sredstva

\section{INTRODUCTION}

\section{UVOD}

Due to its superior properties, wood is used in many structural and non-structural applications. However, due to the difficulties in supplying high-quality wood and the increase in younger, fast-growing and less durable trees, studies on modifications for improving the properties of wood have been accelerated (Rowell, 2012). Many modification processes are currently applied, mainly to improve wood properties such as hygroscopicity, dimensional stability, mechanical strength, biological resistance and UV resistance. Various new technologies such as thermal modification, acetylation, furfurylation and different impregnation and densification processes have been successfully introduced to the market as modern technologies (Sandberg et al., 2017; Lunguleasa et al., 2018).

In order to increase the service life of wood, it is necessary to protect it from damp conditions and prevent dimensional changes (Koski, 2008). Unless necessary measures are taken with wood, high humidity causes undesirable physical changes such as bending, buckling and cracking. In addition, biological pests that require excess moisture to live and develop cause wood to break down. For this reason, it is important to remove excess moisture from the wood and keep its equilibrium moisture content at lower levels. The water absorption rate can be significantly reduced by forming a water repellent barrier in the wood (Williams and Feist, 1999; Koski, 2008).

On the other hand, the dimensional stability of wood can be achieved by blocking the wood cell lumen and reducing the water absorption or bulking and swelling of the cell wall. The impregnation of waterinsoluble materials into the cell wall structure of wood is an effective method for keeping the wood cell wall in a swollen state. This can be achieved by impregnation with a variety of suitable agents, such as natural or synthetic resins, paraffin / wax and vinyl monomers. In this way, the dimensional changes due to moisture differentiation in the wood are significantly reduced (Stamm and Tarkow, 1947; Deka and Saikia, 2000; Kocaefe et al., 2015).

Most properties of wood are closely related to its density. The hardness, wear resistance and other mechanical properties can be improved by modifying the wood via densification. Densification modification is important, especially in order to increase the strength properties of low-density wood species and to enable use in a larger area (Laine et al., 2013;
Sandberg et al., 2013). Densification is based on increasing the material density by decreasing the void volume in the wood. The main aim of wood densification is to improve the mechanical properties of wood (Laine et al., 2013). Wood is generally densified using three different methods. The first is mechanical compression of wood using high pressure under the effect of heat or steam. The second is filling the wood cell cavities with synthetic or natural resins via impregnation. The third is a combination of mechanical compression and impregnation methods (Rowell and Konkol, 1987; Kamke, 2006; Kutnar et al., 2008). The main issue associated with mechanically densified wood is the fixation of the compressed thickness. When exposed to water or heat, mechanically densified wood tends to return to its original dimensions prior to compression (Navi and Heger, 2004; Laine et al., 2013). In order to increase the dimensional stability of densified wood, thermal processes are applied at the time of compression or prior to and following compression. Due to these thermal processes, the dimensional stability of densified wood is significantly increased (Dwianto et al., 1997; Navi and Girardet, 2000; Kamke and Sizemore, 2008; Welzbacher et al., 2008; Fang et al., 2012; Kutnar and Kamke, 2012; Pelit et al., 2016; Kariz et al., 2017). However, thermal processes generally have a negative effect on the hardness or mechanical strength properties of densified wood (Welzbacher et al., 2005; Gong et al., 2010; Kwon et al., 2014; Dubey et al., 2016; Pelit et al., 2018). Another important method for fixing the compressed thickness in densified wood is impregnation with phenolic resins. In the case of wood treated with resins such as phenol and melamine formaldehyde prior to compression, dimensional stability is almost completely achieved. In addition, the mechanical properties of these materials are significantly increased. However, due to the resin properties, the friability of densified wood is also increased (Seborg et al., 1962; Kollmann et al., 1975). In addition, the cost of phenolic resin treatment is high, and the color change in the material to which it is applied is also an important disadvantage (Morsing, 2000).

The aim of this study was to contribute to the literature by determining the effect of pre-impregnation with water-repellent substances (linseed oil, paraffin) and a vinyl monomer (styrene) on the hygroscopicity and dimensional stability of fir (Abies bornmulleriana Mattf.) and aspen (Populus tremula L.) wood densified at different temperatures and compression rates. 


\section{MATERIALS AND METHODS}

\section{MATERIJALI I METODE}

\subsection{Wood samples}

2.1. Uzorci drva

This study used fir (Abies bornmuelleriana Mattf.) and aspen (Populus tremula L.) wood, both of which have relatively low densities (fir: $0.45 \mathrm{~g} / \mathrm{cm}^{3}$, aspen: $\left.0.37 \mathrm{~g} / \mathrm{cm}^{3}\right)$. The wood was selected randomly from a timber company in Düzce, Turkey. Fir and aspen samples were cut from sapwood in rough sizes, in accordance with the study methodology. Attention was paid to ensure that no rot, knots, cracks, or density differences were present in the samples (ISO 3129, 2012). The samples were subjected to natural drying to approximately $12 \%$ moisture content, and then cut to the dimensions of $300 \mathrm{~mm} \times 20 \mathrm{~mm}$ (longitudinal direction $\times$ tangential direction) and three different thicknesses 20 (for undensified samples), 25 and $33.3 \mathrm{~mm}$ (radial direction). Before impregnation, the samples were held in a drying oven at $70{ }^{\circ} \mathrm{C}$ until they reached a stable weight. The samples were then weighed using an analytical balance and their weights were recorded.

\subsection{Impregnation of wood samples}

2.2. Impregnacija uzoraka drva

As water repellents, paraffin (oil ratio: $25-35 \%$, melting point: $61-63{ }^{\circ} \mathrm{C}$ ), linseed oil (density: 0.93-0.95 $\mathrm{g} / \mathrm{cm}^{3}$, drying time: $18-20 \mathrm{~h}$ at $20^{\circ} \mathrm{C}$, packing: in $17 \mathrm{~kg}$ tin) and styrene (density: $0.909 \mathrm{~g} / \mathrm{cm}^{3}$, boiling point: 140 ${ }^{\circ} \mathrm{C}$, packing: in $15 \mathrm{~kg}$ tin) were used as impregnating agents. Pre-treatment procedures were applied to the water-repellent materials before impregnation. The paraffin in solid form was placed in a metal container and

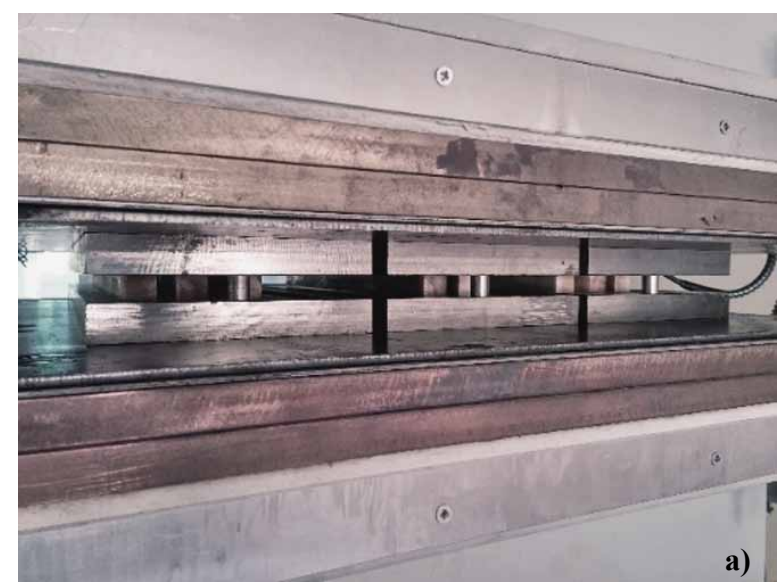

melted by exposure to heat. The linseed oil, which was at its packaged viscosity, was thinned by adding $100 \%$ synthetic thinner. The styrene monomer was mixed with $1 \%$ catalyst (methyl ethyl ketone peroxide) to allow polymerization to take place. Thus, the water repellents were made ready for impregnation. A cylindrical tank assembly with a vacuum holder was used in the impregnation of the wood samples in accordance with ASTM D 1413-76 (1976) standard. With this arrangement, a pre-vacuum equivalent pressure of $760 \mathrm{mmHg}^{-1}$ was applied to the samples for $60 \mathrm{~min}$. The impregnation solutions were then diffused into the samples by holding at atmospheric pressure for $24 \mathrm{~h}$. In order to prevent the melted paraffin from solidifying again, the samples in the paraffin solution were held at $80^{\circ} \mathrm{C}$ for $24 \mathrm{~h}$.

Following the impregnation processes, the excess impregnation solutions were wiped from the samples and they were weighed again and their weights recorded. Afterwards, the paraffin- and linseed-oil treated samples were kept at a constant temperature of $(20 \pm 2)$ ${ }^{\circ} \mathrm{C}$ and relative humidity $(\mathrm{RH})$ of $(65 \pm 3) \%$ in accordance with ISO 13061-1 (2014). The samples treated with styrene monomer were wrapped in aluminum foil and then incubated in an oven at $90^{\circ} \mathrm{C}$ for $2 \mathrm{~h}$ to initiate the polymerization process. These samples were then removed from the oven and immediately densified.

\subsection{Densification process of wood samples}

2.3. Proces ugušćivanja uzoraka drva

The impregnated samples were densified using special metal molds in a hydraulic test press having table dimensions of $60 \mathrm{~cm} \times 60 \mathrm{~cm}$ (Figure 1a). Densification was carried out at three different temperatures and two

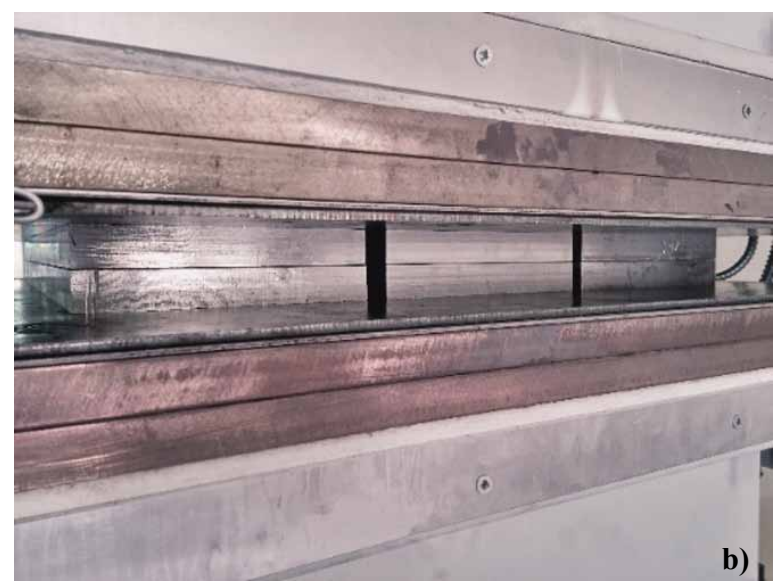

Figure 1 Densification of samples in hot press using metal molds

Slika 1. Ugušćivanje uzoraka u vrućoj preši uz pomoć metalnih kalupa

Table 1 Densification parameters

Tablica 1. Parametri ugušćivanja

\begin{tabular}{|c|c|c|c|}
\hline $\begin{array}{c}\text { Code in study } \\
\text { Oznaka } \text { u istraživanju }\end{array}$ & $\begin{array}{l}\text { Pressing temperature, }{ }^{\circ} \mathbf{C} \\
\text { Temperatura prešanja, }{ }^{\circ} \mathrm{C}\end{array}$ & $\begin{array}{c}\text { Compression ratio, \% } \\
\text { Stupanj ugušćenja, \% }\end{array}$ & $\begin{array}{c}\text { Duration } \\
\text { Trajanje } \\
\end{array}$ \\
\hline A1 & 120 & 20 & \multirow{6}{*}{$\begin{array}{c}10 \text { min heating } \\
+ \\
20 \text { min pressure } \\
10 \text { min zagrijavanje } \\
+ \\
20 \text { min prešanje }\end{array}$} \\
\hline A2 & 120 & 40 & \\
\hline B1 & 150 & 20 & \\
\hline B2 & 150 & 40 & \\
\hline $\mathrm{C} 1$ & 180 & 20 & \\
\hline $\mathrm{C} 2$ & 180 & 40 & \\
\hline
\end{tabular}


different compression rates. The parameters applied in the densification of the samples are given in Table 1.

Channels $10 \mathrm{~mm}$ in depth and $20 \mathrm{~mm}$ wide were opened in the metal molds used for densification. The 25 and $33.3 \mathrm{~mm}$ thick samples were placed in the channels, the tables had been pre-heated at the specified temperatures for $10 \mathrm{~min}$ and the compression of the samples was then carried out in the radial orientation with a loading speed of $60 \mathrm{~mm} / \mathrm{min}$. In order to achieve the targeted thickness $(20 \mathrm{~mm})$, the load was maintained until the metal molds came into contact with each other (Figure 1b).

The compressed samples were kept under pressure for $20 \mathrm{~min}$ and then were removed from the press together with the molds and cooled to room temperature under an average pressure of $0.5 \mathrm{MPa}$ in order to minimize the spring-back effect. According to ISO 13061-1 (2014), after the densification process, samples remained in a conditioning cabin at $(20 \pm 2){ }^{\circ} \mathrm{C}$ and $(65 \pm 3) \% \mathrm{RH}$ until they reached a stable weight. The impregnated and densified samples were then cut into smaller samples according to the standard of the selected tests. The test samples were prepared in a number sufficient to accommodate eight repetitions $(n=8)$ for each variable.

\subsection{Determination of retention}

2.4. Određivanje retencije

The retention values of the wood samples impregnated with water repellents were determined using Eq. 1,

$$
\text { Retention }\left(\mathrm{kg} / \mathrm{m}^{3}\right)=(G \times C) / V \times 10
$$

where $G$ is the amount ( $\mathrm{g}$ ) of water repellent absorbed by the samples, $C$ is the concentration of the water repellent solution, and $V$ is the volume $\left(\mathrm{cm}^{3}\right)$ of the wood samples.

\subsection{Determination of dimensional changes \\ 2.5. Određivanje dimenzijskih promjena}

Compressed wood has a tendency to partially regain its original shape after the removal of applied pressure due to elastic recovery. This behavior is known as spring-back and results in changes in the compressed dimensions (Garcia-Romeu et al., 2007). The springback $(S B)$ values of the samples were calculated using Eq. 2. In addition, compression recovery rate $(C R R)$ (or set recovery) of the densified samples after immersion in water was determined using Eq. 3 (Pelit et al., 2014),

$$
\begin{gathered}
S B(\%)=\left[\left(T_{3}-T_{2}\right) / T_{2}\right] \times 100 \\
C R R(\%)=\left[\left(T_{4}-T_{3}\right) /\left(T_{1}-T_{3}\right)\right] \times 100
\end{gathered}
$$

where $T_{1}$ is the initial thickness of samples before pressing, $T_{2}$ is the thickness of samples under pressure (load), $T_{3}$ is the thickness of samples conditioned at $(20 \pm 2){ }^{\circ} \mathrm{C}$ and $(65 \pm 3) \% \mathrm{RH}$ for eight weeks after pressing, and $T_{4}$ is the thickness of samples after submersion in water for three weeks.

Thickness swelling (TS) of wood samples was determined according to ISO 13061-15 (2017). The TS value were calculated using Eq. 4 ,

$$
T S(\%)=\left[\left(T_{4}-T_{0}\right) / T_{0}\right] \times 100
$$

where $T_{0}$ is the oven-dry thickness of samples after holding at $55^{\circ} \mathrm{C}$ for $72 \mathrm{~h}$.

\subsection{Determination of hygroscopicity}

2.6. Određivanje higroskopnosti

Equilibrium moisture content (EMC) of the samples was determined according to ISO 13061-1 (2014). The EMC was calculated using Eq. 5,

$$
\operatorname{EMC}(\%)=\left[\left(W_{1}-W_{0}\right) / W_{0}\right] \times 100
$$

where $W_{1}$ is the weight of samples conditioned at (20 \pm 2$)$ ${ }^{\circ} \mathrm{C}$ and $(65 \pm 3) \% \mathrm{RH}$ for eight weeks and $W_{0}$ is the ovendry weight of samples after holding at $55^{\circ} \mathrm{C}$ (a temperature below the melting point of paraffin) for $72 \mathrm{~h}$.

Water absorption (WA) of the samples was determined in parallel with the thickness swelling test. The $W A$ was calculated using Eq. 6. In addition, water repellent effectiveness (WRE) values calculated for impregnated samples as compared to untreated samples were determined using Eq. 7,

$$
\begin{gathered}
W A(\%)=\left[\left(W_{2}-W_{0}\right) / W_{0}\right] \times 100 \\
W R E(\%)=\left[\left(W A_{c}-W A_{t}\right) / W A_{c}\right] \times 100
\end{gathered}
$$

where $W_{2}$ is the weight of samples after submersion in water for three weeks, $W A_{c}$ is the percentage of water absorption of the untreated samples and $W A_{t}$ is the percentage of water absorption of the impregnated samples.

\subsection{Statistical analyses \\ 2.7. Statistička analiza}

Analysis of variance (ANOVA) tests were performed to determine the effect of water repellents on the hygroscopicity and dimensional stability of the densified fir and aspen wood at the 0.05 significance level. Significant differences between the groups were compared using Duncan's test.

\section{RESULTS AND DISCUSSION}

3. REZULTATI I RASPRAVA

\subsection{Retention}

\subsection{Retencija}

\begin{tabular}{|c|c|c|c|}
\hline \multirow{2}{*}{$\begin{array}{l}\text { Wood species } \\
\text { Vrsta drva }\end{array}$} & \multicolumn{3}{|c|}{$\begin{array}{c}\text { Water repellents } \\
\text { Vodoodbojno sredstvo }\end{array}$} \\
\hline & $\begin{array}{l}\text { Paraffin } \\
\text { Parafin }\end{array}$ & $\begin{array}{l}\text { Linseed oil } \\
\text { Laneno ulje }\end{array}$ & \begin{tabular}{|c|} 
Styrene \\
Stiren
\end{tabular} \\
\hline Fir / jelovina & $\begin{array}{l}148.08 \\
(9.47)\end{array}$ & $\begin{array}{l}230.09 \\
(20.38)\end{array}$ & \begin{tabular}{|l|}
300.37 \\
$(18.17)$ \\
\end{tabular} \\
\hline Aspen / jasikovina & $\begin{array}{l}155.35 \\
(10.04)\end{array}$ & $\begin{array}{l}230.16 \\
(21.41)\end{array}$ & \begin{tabular}{|l|}
311.56 \\
$(21.71)$ \\
\end{tabular} \\
\hline
\end{tabular}

The retention values of the fir and aspen wood samples determined after impregnation with water repellents are shown in Table 2. According to the findings, the highest retention value for both wood species

Table 2 Retention values of fir and aspen wood $\left(\mathrm{kg} / \mathrm{m}^{3}\right)$

Tablica 2. Vrijednosti retencije drva jele i drva jasike $\left(\mathrm{kg} / \mathrm{m}^{3}\right)$

Values in parenthesis are standard deviations. / Vrijednosti $u$ zagradama standardne su devijacije. 
was obtained in samples impregnated with styrene and the lowest in paraffin-impregnated samples.

\subsection{Spring-back, compression recovery rate and} thickness swelling

3.2. Povrat, stupanj povrata ugušćenja i debljinsko bubrenje

According to ANOVA results, the effect of water repellent type and densification condition factors on the spring-back $(S B)$, compression recovery rate $(C R R)$ and thickness swelling (TS) for fir and aspen woods was statistically significant $(p \leq 0.05)$. Duncan's oneway comparison results conducted for the factors of water repellents and densification are given in Table 3.

Regarding water repellents, for the fir wood, the highest $S B$ average was determined in the non-impregnated (untreated) samples (5.49\%), and the lowest in the samples impregnated with paraffin (3.09\%). For aspen wood, the highest SB was obtained in the samples impregnated with linseed oil (5.42\%) and the lowest in the paraffin-impregnated samples (3.58\%) (Table 3). The $S B$ values were higher in both wood species impregnated with styrene and compressed at $120^{\circ} \mathrm{C}$ (under conditions $A 1$ and $A 2$ ) (Figure 2a). However, the SB values were significantly reduced in samples that were impregnated with styrene and compressed at elevated temperatures (especially at $180{ }^{\circ} \mathrm{C}$ ). Compared to the untreated samples condensed under $C 2$ conditions, the $\mathrm{SB}$ values in the styrene-impregnated fir and aspen wood samples decreased by $80.9 \%$ and $81.1 \%$, respec- tively. The styrene monomer absorbed by the wood samples was more likely to evaporate from the material at a high compression temperature. As a result of this situation, it can be said that the SB results were affected by the decrease in high internal stresses formed in the compressed wood due to the excess impregnation chemical. In addition, the decrease in the $E M C$ ratios of the samples due to the increase in the compression temperature may have affected the SB results. For fir wood, in general, the SB values were decreased in samples impregnated with paraffin and linseed oil compared to untreated samples. In fir wood impregnated with paraffin and densified under $C 2$ conditions, SB results close to those of the styrene-treated samples were obtained. For aspen wood, the SB value of samples impregnated with paraffin was found to be near to or lower than that of the untreated samples. However, compared to untreated samples, the SB values were higher in aspen samples impregnated with linseed oil. Generally, in the evaluation of water repellents, the untreated and paraffin-impregnated samples yielded more positive results with densification applications at a low temperature $\left(120^{\circ} \mathrm{C}\right)$, while quite successful results were obtained in samples impregnated with styrene via densification applications at a high temperature $\left(180^{\circ} \mathrm{C}\right)$. Moreover, in both tree species impregnated with paraffin, $\mathrm{SB}$ values were lower than those of linseed oil (Figure 2a).

With respect to densification variables, the highest SB average for fir wood was found in samples

Table 3 Duncan's test results for mean values of $S B, C R R$, and $T S$

Tablica 3. Rezultati srednjih vrijednosti za $S B, C R R$ i $T S$ prema Duncanovu testu

\begin{tabular}{|c|c|c|c|c|c|c|c|}
\hline \multirow{2}{*}{$\begin{array}{l}\text { Wood specie } \\
\text { Vrsta drva }\end{array}$} & \multirow{2}{*}{$\begin{array}{c}\text { Factor } \\
\text { Ćimbenik }\end{array}$} & \multicolumn{2}{|c|}{$S B, \%$} & \multicolumn{2}{|c|}{$C R R, \%$} & \multicolumn{2}{|c|}{$T S, \%$} \\
\hline & & Mean & SG & Mean & SG & Mean & SG \\
\hline \multirow{13}{*}{$\begin{array}{l}\text { Fir wood } \\
\text { drvo jele }\end{array}$} & Water repellents / Vodoodbojna sredstva & & & & & & \\
\hline & Untreated / netretirano & 5.49 & a & 93.32 & $\mathrm{a}$ & 34.43 & $\mathrm{a}$ \\
\hline & Paraffin / parafin & 3.09 & $\mathrm{c}$ & 87.27 & $\mathrm{~b}$ & 31.51 & $\mathrm{~b}$ \\
\hline & Linseed oil / laneno ulje & 4.45 & $\mathrm{~b}$ & 71.42 & $\mathrm{c}$ & 26.32 & $\mathrm{c}$ \\
\hline & Styrene / stiren & 4.44 & $\mathrm{~b}$ & 31.26 & $\mathrm{~d}$ & 10.56 & $\mathrm{~d}$ \\
\hline & Densification / Ugušćivanje & & & & & & \\
\hline & Undensified / neugušćeno & - & - & - & - & 3.37 & g \\
\hline & A1 & 3.14 & $\mathrm{e}$ & 85.36 & $\mathrm{a}$ & 20.93 & $\mathrm{~d}$ \\
\hline & A2 & 5.28 & $\mathrm{~b}$ & 75.79 & $\mathrm{c}$ & 48.49 & $\mathrm{a}$ \\
\hline & B1 & 4.21 & $\mathrm{~d}$ & 81.29 & $\mathrm{~b}$ & 18.65 & $\mathrm{e}$ \\
\hline & $\mathrm{B} 2$ & 5.66 & $\mathrm{a}$ & 68.84 & $\mathrm{~d}$ & 42.28 & $\mathrm{~b}$ \\
\hline & $\mathrm{C} 1$ & 3.22 & $\mathrm{e}$ & 64.03 & $\mathrm{e}$ & 15.01 & $\mathrm{f}$ \\
\hline & $\mathrm{C} 2$ & 4.70 & $\mathrm{c}$ & 49.60 & $\mathrm{f}$ & 31.21 & $\mathrm{c}$ \\
\hline \multirow{13}{*}{$\begin{array}{l}\text { Aspen wood } \\
\text { drvo jasike }\end{array}$} & Water repellents / Vodoodbojna sredstva & & & & & & \\
\hline & Untreated / netretirano & 4.40 & $\mathrm{~b}$ & 88.59 & $\mathrm{~b}$ & 32.62 & $\mathrm{a}$ \\
\hline & Paraffin / parafin & 3.58 & $\mathrm{~d}$ & 91.37 & $\mathrm{a}$ & 32.20 & $\mathrm{a}$ \\
\hline & Linseed oil / laneno ulje & 5.42 & $\mathrm{a}$ & 80.07 & $\mathrm{c}$ & 27.69 & $\mathrm{~b}$ \\
\hline & Styrene / stiren & 3.99 & $\mathrm{c}$ & 30.39 & $\mathrm{~d}$ & 8.43 & $\mathrm{c}$ \\
\hline & Densification / Ugušćivanje & & & & & & \\
\hline & Undensified / neugušćeno & - & - & - & - & 3.11 & $\mathrm{~g}$ \\
\hline & A1 & 3.99 & $\mathrm{~d}$ & 92.29 & $\mathrm{a}$ & 21.71 & $\mathrm{~d}$ \\
\hline & $\mathrm{A} 2$ & 5.53 & $\mathrm{a}$ & 75.02 & $\mathrm{c}$ & 47.12 & $\mathrm{a}$ \\
\hline & B1 & 3.57 & $\mathrm{e}$ & 80.97 & $\mathrm{~b}$ & 17.20 & $\mathrm{e}$ \\
\hline & $\mathrm{B} 2$ & 5.25 & $\mathrm{~b}$ & 67.02 & $\mathrm{~d}$ & 40.10 & $\mathrm{~b}$ \\
\hline & $\mathrm{C} 1$ & 3.37 & $\mathrm{f}$ & 67.09 & $\mathrm{~d}$ & 14.85 & $\mathrm{f}$ \\
\hline & $\mathrm{C} 2$ & 4.37 & $\mathrm{c}$ & 53.25 & $\mathrm{e}$ & 32.55 & $\mathrm{c}$ \\
\hline
\end{tabular}

$S G$ : statistical group (different letters denote a significant difference). / SG: statistička grupa (različita slova označavaju značajnu razliku). 
densified under $B 2$ conditions $(5.66 \%)$ and the lowest in the samples densified under $A 1$ and $C 1$ conditions $(3.14 \%$ and $3.22 \%)$. The highest SB for aspen wood was determined in the samples densified under $A 2$ conditions $(5.53 \%)$, whereas the lowest was for samples densified under $C 1$ conditions $(3.37 \%$ ) (Table 3$)$. The
SB values of the densified fir and aspen samples varied depending on the compression rate and temperature. For both tree species, SB values were higher in the samples densified at the compression rate of $40 \%$ compared to the $20 \%$ compression rate (Figure $2 \mathrm{a}$ ). In other words, the SB values had increased due to the

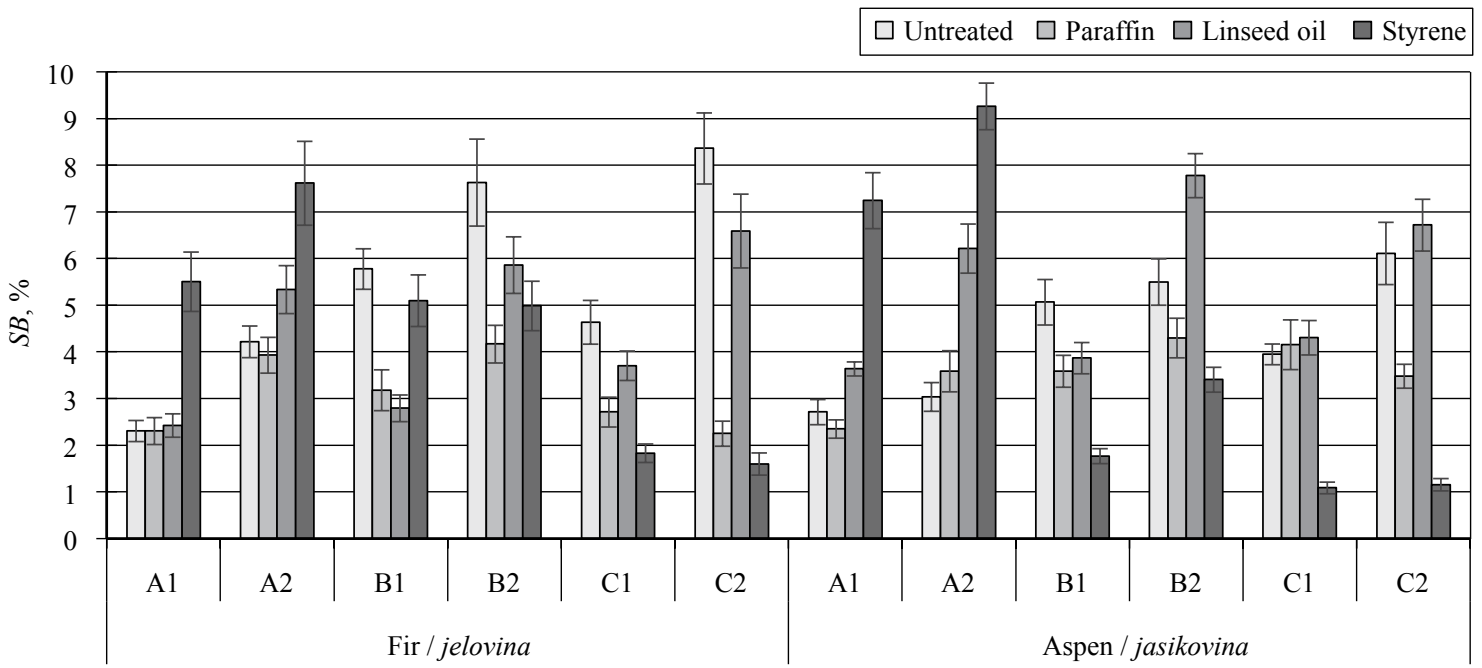

(a)

$\square$ Untreated $\square$ Paraffin $\square$ Linseed oil $\square$ Styrene

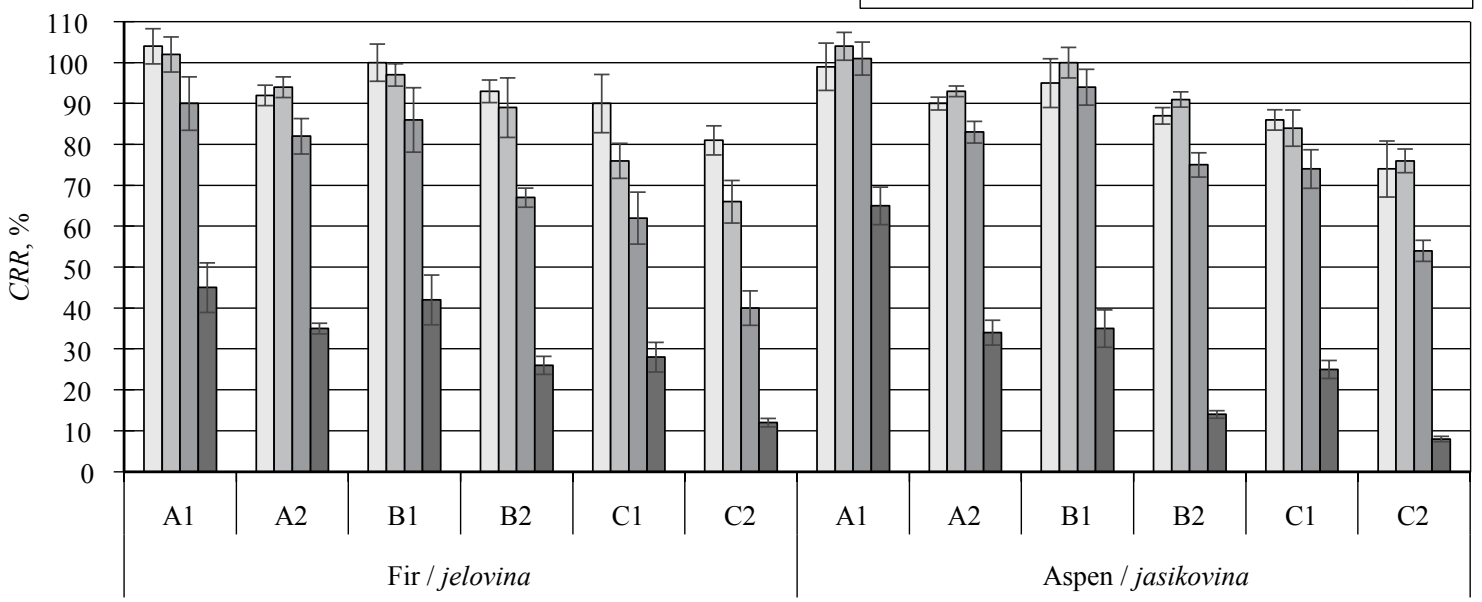

(b)

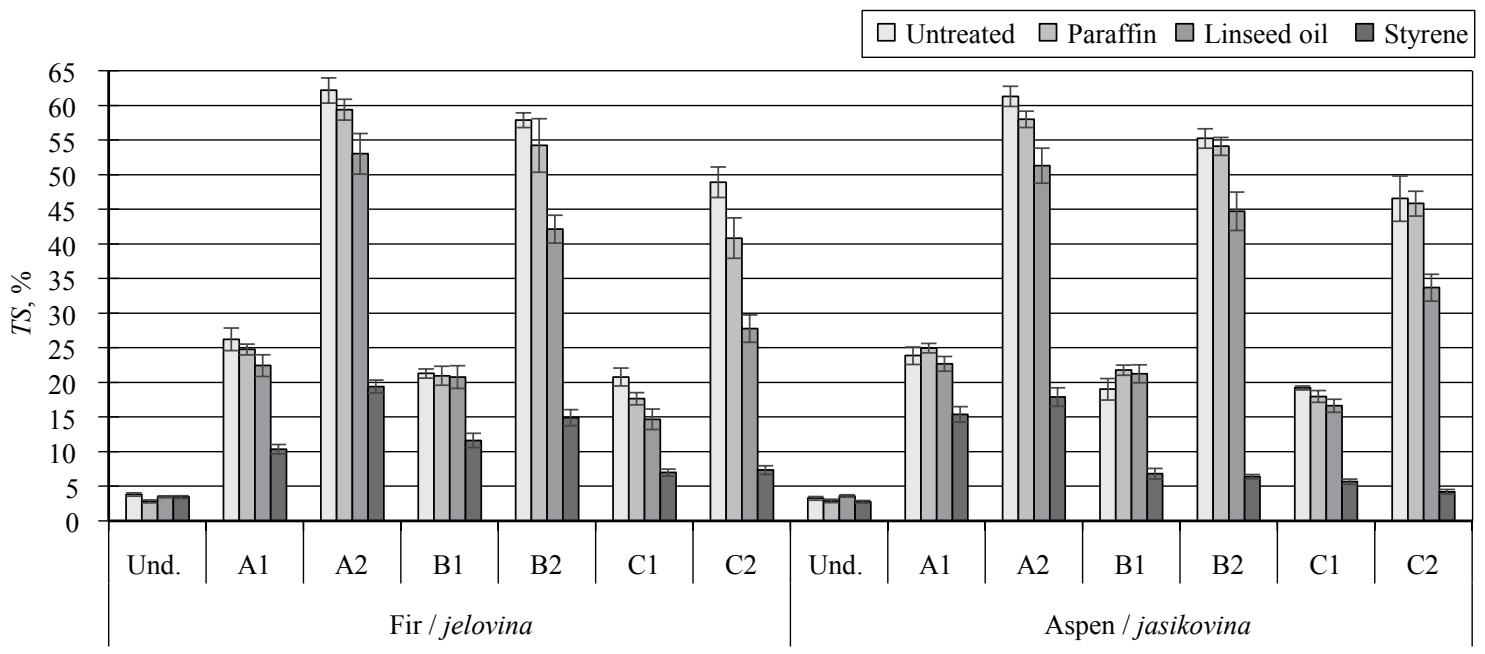

(c)

Figure $2 S B, C R R$ and $T S$ for fir and aspen wood depending on densification conditions

Slika 2. $S B, C R R$ i $T S$ za drvo jele i drvo jasike u ovisnosti o uvjetima ugušćivanja 
increase in the compression rate. In the literature, it has been reported that increased internal stress in the material during the wood densification process resulting from increase in the compression rate leads to higher $S B$ values (Wolcott et al., 1989; Nairn, 2006; Pelit et al., 2016). In the untreated samples and in those impregnated with linseed oil, SB values increased due to an increase in the compression temperature. However, especially in samples impregnated with styrene, as a result of the higher compression temperature, SB values decreased significantly.

With respect to water repellents, the highest $C R R$ average for fir wood was found in untreated samples $(93.32 \%)$, and for aspen wood in samples impregnated with paraffin $(91.37 \%)$. The lowest $C R R$ average was determined in styrene-impregnated samples for both wood species (31.26\% for fir and $30.39 \%$ for aspen) (Table 3). In both species impregnated with water repellent agents (except for the paraffin-impregnated aspen samples), the $C R R$ values were reduced (Figure $2 \mathrm{~b})$. The $C R R$ values in the samples impregnated with linseed oil were lower than in the untreated samples. However, the most significant reduction in $C R R$ values was detected in the styrene-treated samples. The $C R R$ values of the styrene-impregnated fir and aspen woods were reduced by $85 \%$ and $89 \%$, respectively, compared to untreated samples densified under the same conditions. With the styrene pretreatment, the compressed thickness of the densified samples exposed to water over a long period was almost completely retained (Figure $2 b$ ). As for the results, it can be said that the significantly reduced water absorption of the styrene-treated samples was effective (Figure $3 b$ ). Chao and Lee (2003) reported that the polymerized hydrophobic styrene monomer remained in the cell wall and lumen of the impregnated wood and formed a barrier on the wood surface, resulting in less water entering the wood. This greatly reduced the water absorption and dimensional changes of wood. Furthermore, water repellency and dimensional stability have been reported to increase significantly in wood treated with vinyl monomers compared to untreated wood (Rowell, 2012).

Regarding densification conditions, the highest $C R R$ average was determined for both tree species in samples densified under $A 1$ conditions ( $85.36 \%$ for fir and $92.29 \%$ for aspen) and the lowest for samples densified under $C 2$ conditions (49.60\% for fir and $53.25 \%$ for aspen) (Table 3). At all temperature levels, $C R R$ values were significantly lower in the fir and aspen samples compressed at a higher rate (40\%) (Figure $2 \mathrm{~b})$. In the densification process, with the higher compression rate, deformations such as fractures, cracking and collapse of the wood cell wall also increased (Tabarsa and Chui, 1997; Dogu et al., 2010; Budakci et al., 2016; Bekhta et al., 2017). It can be said that the increase in the amount and size of deformation in the densified wood reduced the tendency of the cell to recover its initial shape and this situation had an effect on the $C R R$ results. In addition, at the same compression rate $(20 \%$ or $40 \%$ ), the $C R R$ values were lower in the samples which were densified at a higher temperature. The increase in densification temperature had a positive effect on the $C R R$ results of both untreated and impregnated samples, especially in those treated with styrene.

Regarding water repellents, the highest $T S$ average in the untreated samples was $34.43 \%$ for fir and $32.62 \%$ aspen, while the lowest was obtained in the styrene-impregnated samples with $10.56 \%$ for fir and $8.43 \%$ for aspen (Table 3 ). It was observed that impregnation with water-repellents did not have much impact on the $T S$ values of the undensified samples (Figure 2c). However, the pre-impregnation processes in the densified samples generally reduced the $T S$ values. More positive results were obtained in linseed oil-treated samples compared to paraffin-treated samples. Positive results for the $T S$ values were mainly determined in the styrene-treated samples. The $T S$ values decreased significantly in these samples depending on the compression rate and temperature. In particular, under $C 2$ conditions, the $T S$ values of the densified styrenepretreated samples were close to those of the control (undensified) samples. The $T S$ values of styrene-treated fir and aspen samples were reduced by $85 \%$ and $91 \%$, respectively, compared to the untreated samples densified under the same conditions. In the literature, it was reported that in agathis wood impregnated before compression with vinyl monomers (styrene and methyl methacrylate), dimensional stability increased due to changes in the cellular structure and chemical components (i.e., cellulose crystallinity, microfibril angle and preferred orientation of fibers) as well as degradation of cellulose (Khalil et al., 2014). In addition, it was reported that polymerization of styrene in wood can result in the grafting of the styrene to cellulose, lignin, and pentosans (Rowell, 2012). Moreover, it was found that water-repellent efficacy and dimensional stability properties improved as a result of in situ polymerization of vinyl monomers filling wood cell voids (Rowell and Konkol, 1987).

With respect to densification conditions, the highest $T S$ average was found in densified samples under $A 2$ conditions ( $48.49 \%$ for fir and $47.12 \%$ for aspen), whereas the lowest was in undensified samples (3.37\% for fir and $3.11 \%$ for aspen) (Table 3 ). According to Figure 2c, the $T S$ values of all the densified samples were higher than those of the undensified samples. In densified samples, $T S$ values increased with the higher compression rate. In general, a higher $T S$ was obtained at the compression rate of $40 \%$ than at $20 \%$. The fact that the densified samples exposed to water tended to return to their initial pre-compression dimensions can be said to affect the results (Seborg et al., 1962; Kollmann et al., 1975; Pelit et al., 2014). As an exception, $T S$ values were found to be lower in the styrene-pretreated aspen samples densified under $B 2$ and $C 2$ conditions. This can be explained by the fact that the polymerization of the styrene monomer within the densified wood was more effective at high temperatures $\left(150{ }^{\circ} \mathrm{C}\right.$ and $\left.180{ }^{\circ} \mathrm{C}\right)$. In terms of compression temperature, the highest $T S$ value was determined in the samples densified at $120^{\circ} \mathrm{C}$ and the lowest in the samples densified at $180{ }^{\circ} \mathrm{C}$. In the densified fir and 
aspen samples, the $T S$ values were reduced due to the increase in compression temperature.

\subsection{Equilibrium moisture content, water} absorption and water repellent effectiveness

3.3. Ravnotežni sadržaj vode, upojnost uzoraka i učinkovitost vodoodbojnih sredstava

The effect of water repellent type and densification condition factors on the equilibrium moisture content $(E M C)$, water absorption $(W A)$, and water repellent effectiveness $(W R E)$ for both wood species was statistically significant. Duncan's one-way comparison results conducted for mean values of $E M C, W A$, and WRE are shown in Table 4.

Regarding water repellents, the highest mean $E M C$ was found for untreated samples $(10.22 \%$ for fir and $9.77 \%$ for aspen) and the lowest for styrene-impregnated samples $(6.63 \%$ for fir and $5.43 \%$ for aspen) (Table 4). The EMC decreased in all samples impregnated with water repellents (Figure 3a). A lower $E M C$ was determined in the paraffin-treated samples compared to the linseed oil-treated samples. The lowest $E M C$ for both wood species was measured in the styrene-treated samples. Due to the increase in the compression rate and temperature, the $E M C$ was significantly reduced in the styrene-pretreated wood samples, while the hygroscopicity resistance of the samples increased. In the styrene pre-treated fir and aspen wood densified under $C 2$ conditions, the $E M C$ was reduced by $53 \%$ and $67 \%$, respectively, relative to untreated samples.
Regarding densification variables, the highest $E M C$ average was determined in undensified samples (48.49\% for fir and $47.12 \%$ for aspen), while the lowest was in densified samples under $C 2$ conditions (3.37\% for fir and $3.11 \%$ for aspen) (Table 4). According to Figure $3 \mathrm{a}$, the $E M C$ value of the densified samples was generally lower than that of the undensified samples. The effect of the compression rate on EMC was not significant in the paraffin- and linseed-treated samples. However, the EMC decreased in the styrenetreated samples due to a higher compression rate. Similarly, the effect of the compression temperature on $E M C$ in the paraffin- and linseed oil-treated samples was not apparent, while in the styrene-treated fir and aspen samples, the $E M C$ was decreased due to a high compression temperature. The lowest $E M C$ was determined in the samples compressed at $180^{\circ} \mathrm{C}$.

With respect to water repellents, the highest $W A$ average was found in untreated samples (137.98\% for fir and $171.61 \%$ for aspen) and the lowest in the styrene-impregnated samples $(52.67 \%$ for fir and $52.59 \%$ for aspen) (Table 4). The $W A$ was also reduced in both tree species impregnated with water repellents (Figure $3 b)$. Depending on the substances used and their quantities, water repellents fill the cell cavities and are stored on the outer surfaces and partially on the inner surfaces. Thus, the wood surface exhibits hydrophobicity and the water intake rate is reduced (Dizman Tomak and Y1ld1z, 2012). In general, the $W A$ was found to be

Table 4 Duncan's test results for mean values of $E M C, W A$, and $W R E$

Tablica 4. Rezultati srednjih vrijednosti za $E M C, W A$ i $W R E$ prema Duncanovu testu

\begin{tabular}{|c|c|c|c|c|c|c|c|}
\hline \multirow{2}{*}{$\begin{array}{c}\text { Wood species } \\
\text { Vrsta drva }\end{array}$} & \multirow{2}{*}{$\begin{array}{c}\text { Factor } \\
\text { Čimbenik }\end{array}$} & \multicolumn{2}{|c|}{$E M C, \%$} & \multicolumn{2}{|c|}{$W A, \%$} & \multicolumn{2}{|c|}{$W R E, \%$} \\
\hline & & Mean & SG & Mean & SG & Mean & SG \\
\hline \multirow{13}{*}{$\begin{array}{l}\text { Fir wood } \\
\text { drvo jele }\end{array}$} & Water repellents / Vodoodbojna sredstva & & & & & & \\
\hline & Untreated / netretirano & 10.22 & $\mathrm{a}$ & 137.98 & $\mathrm{a}$ & - & - \\
\hline & Paraffin / parafin & 8.14 & $\mathrm{c}$ & 92.01 & $\mathrm{c}$ & 33.25 & $\mathrm{~b}$ \\
\hline & Linseed oil / laneno ulje & 9.02 & $\mathrm{~b}$ & 96.17 & $\mathrm{~b}$ & 29.94 & $\mathrm{c}$ \\
\hline & Styrene / stiren & 6.63 & $\mathrm{~d}$ & 52.67 & $\mathrm{~d}$ & 61.07 & $\mathrm{a}$ \\
\hline & Densification / Ugušćivanje & & & & & & \\
\hline & Undensified / neugušćeno & 9.94 & $\mathrm{a}$ & 82.23 & $\mathrm{e}$ & 54.55 & $\mathrm{a}$ \\
\hline & A1 & 8.98 & $\mathrm{~b}$ & 96.46 & $\mathrm{c}$ & 36.82 & $\mathrm{~d}$ \\
\hline & A2 & 8.66 & $\mathrm{c}$ & 105.97 & $\mathrm{a}$ & 40.14 & $\mathrm{~cd}$ \\
\hline & B1 & 8.69 & bc & 96.81 & $\mathrm{c}$ & 30.81 & $\mathrm{e}$ \\
\hline & B2 & 7.86 & $\mathrm{~d}$ & 101.39 & $\mathrm{~b}$ & 41.32 & $\mathrm{c}$ \\
\hline & $\mathrm{C} 1$ & 8.06 & $\mathrm{~d}$ & 90.09 & $\mathrm{~d}$ & 37.69 & $\mathrm{~d}$ \\
\hline & $\mathrm{C} 2$ & 7.33 & $\mathrm{e}$ & 90.01 & $\mathrm{~d}$ & 48.59 & $\mathrm{~b}$ \\
\hline \multirow{13}{*}{$\begin{array}{l}\text { Aspen wood } \\
\text { drvo jasike }\end{array}$} & Water repellents / Vodoodbojna sredstva & & & & & & \\
\hline & Untreated / netretirano & 9.77 & $\mathrm{a}$ & 171.61 & $\mathrm{a}$ & - & - \\
\hline & Paraffin / parafin & 7.57 & $\mathrm{c}$ & 114.29 & $\mathrm{c}$ & 33.12 & $\mathrm{~b}$ \\
\hline & Linseed oil / laneno ulje & 8.57 & $\mathrm{~b}$ & 127.29 & $\mathrm{~b}$ & 25.59 & c \\
\hline & Styrene / stiren & 5.43 & $\mathrm{~d}$ & 52.59 & $\mathrm{~d}$ & 69.44 & $\mathrm{a}$ \\
\hline & Densification / Ugušćivanje & & & & & & \\
\hline & Undensified / neugušćeno & 9.46 & $\mathrm{a}$ & 126.77 & $\mathrm{a}$ & 43.76 & $\mathrm{~b}$ \\
\hline & A1 & 8.34 & $\mathrm{~b}$ & 125.50 & $\mathrm{ab}$ & 37.17 & $\mathrm{c}$ \\
\hline & $\mathrm{A} 2$ & 7.57 & $\mathrm{~d}$ & 121.87 & $\mathrm{bc}$ & 41.84 & $\mathrm{~b}$ \\
\hline & B1 & 7.86 & $\mathrm{c}$ & 109.64 & $\mathrm{~d}$ & 41.54 & $\mathrm{~b}$ \\
\hline & $\mathrm{B} 2$ & 7.42 & $\mathrm{~d}$ & 119.87 & $\mathrm{c}$ & 42.58 & $\mathrm{~b}$ \\
\hline & $\mathrm{C} 1$ & 7.53 & $\mathrm{~d}$ & 107.04 & de & 41.66 & $\mathrm{~b}$ \\
\hline & $\mathrm{C} 2$ & 6.68 & $\mathrm{e}$ & 104.42 & $\mathrm{e}$ & 50.47 & $\mathrm{a}$ \\
\hline
\end{tabular}

SG: statistical group (different letters denote a significant difference). / SG: statistička grupa (različita slova označavaju značajnu razliku). 


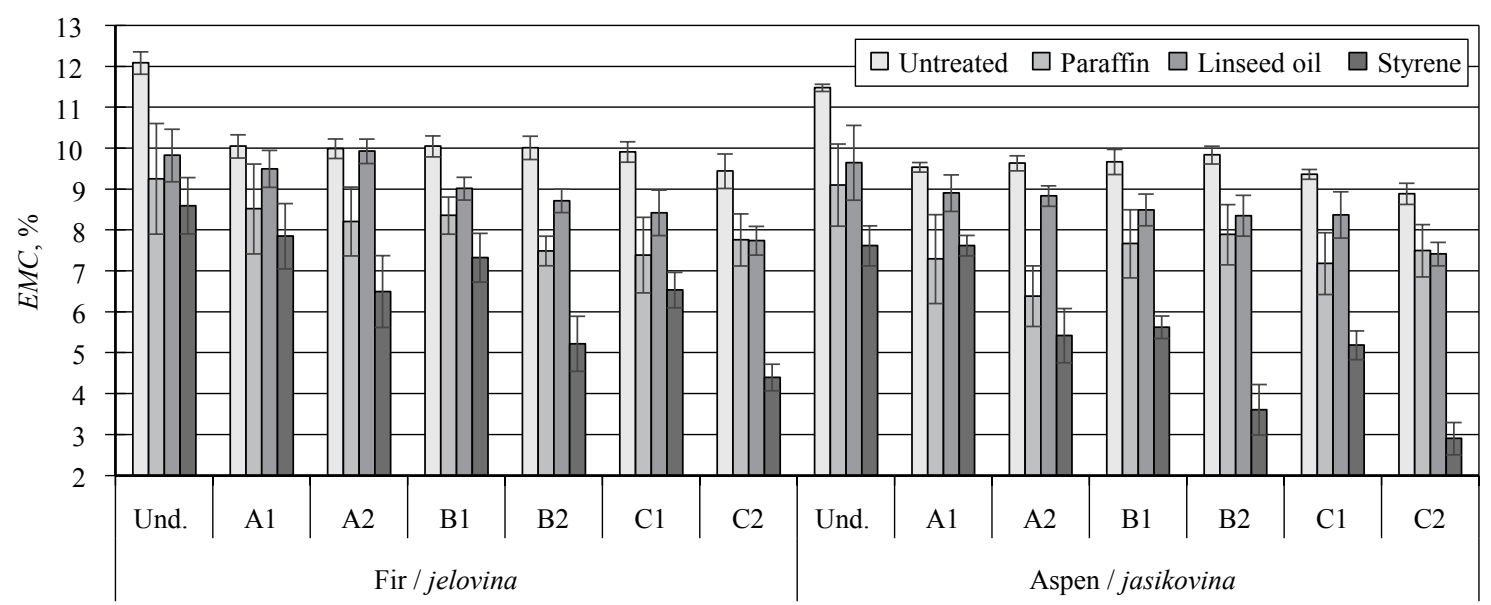

(a)

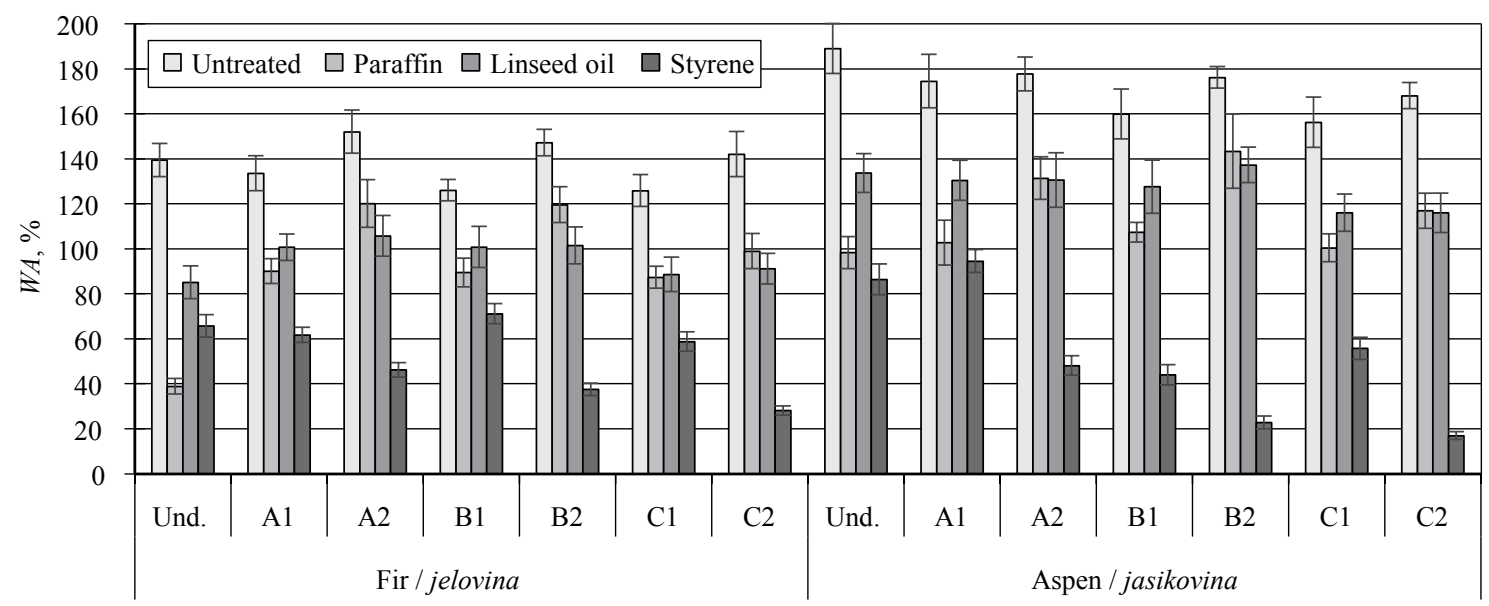

(b)

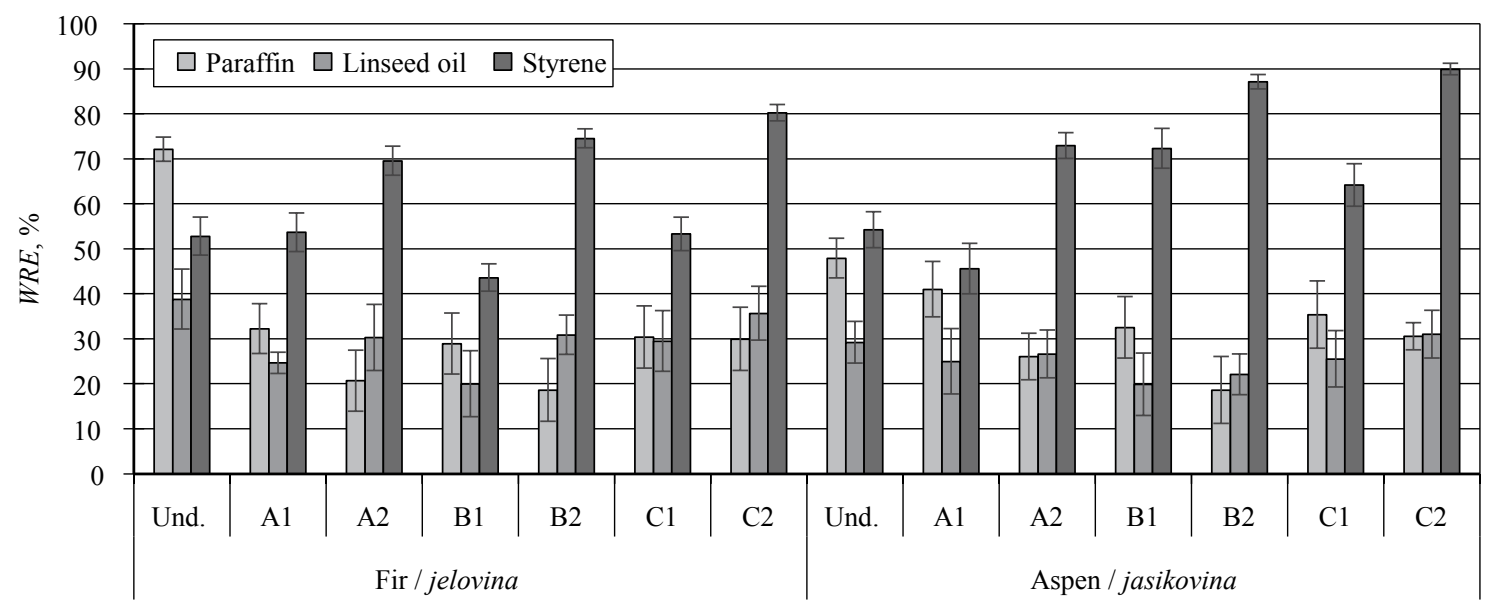

(c)

Figure $3 E M C, W A$ and $W R E$ for fir and aspen wood depending on densification conditions

Slika 3. $E M C, W A$ i $W R E$ za drvo jele i drvo jasike u ovisnosti o uvjetima ugušćivanja

lower in paraffin-treated samples compared to linseed oil-treated samples. However, the most positive results for $W A$ were determined in the styrene-treated samples. In these samples, the $W A$ was significantly reduced, especially after high temperature $\left(180^{\circ} \mathrm{C}\right)$ and high compression $(40 \%)$. Compared to untreated samples, the $W A$ decreased $80 \%$ and $90 \%$, respectively, in styrene pre-treated fir and aspen woods densified under $C 2$ conditions $\left(180^{\circ} \mathrm{C} / 40 \%\right)$. When wood is impregnated with vinyl monomers, the polymer is located almost completely in the lumen of the wood and only a small amount is polymerized in the cell wall. Consequently, the $W A$ is significantly reduced in woods with polymers filling the volume of the cavities (Baysal et al., 2007; Rowell, 2012). In previous studies, it was reported that water absorption decreased significantly in styrene-treated wood compared to untreated wood. (Yalinkilic et al. 1998; Chao and Lee, 2003; Baysal et al., 2006).

Regarding densification factors, the highest $W A$ average for fir wood was found in samples densified 
under $A 2$ conditions (105.97\%) and for aspen wood in undensified samples (126.77\%). The lowest $W A$ average was determined in undensified samples for fir wood $(82.23 \%)$ and for aspen wood in samples densified under $C 2$ conditions (104.42\%) (Table 4). In densified samples (except for styrene-pretreated samples), the $W A$ values increased due to a higher compression rate. The $W A$ was generally higher at $40 \%$ compression rate than at $20 \%$ (Figure $3 \mathrm{~b}$ ). It can be said that the increase in the amount of water-repellent agents moving away from the wood with the increase of compression rate affect the results. Depending on the amount of water repellent impregnated into wood, hydrophobic properties of wood increase (Koski, 2008). The effect of the compression temperature on the $W A$ in the untreated, paraffin-treated and linseed oil-treated samples was not very pronounced. However, in the styrene-treated samples, the $W A$ was reduced as a result of a higher compression temperature.

Regarding water repellents, the highest WRE average was found in samples impregnated with styrene $(61.07 \%$ for fir and $69.44 \%$ for aspen), and the lowest in samples impregnated with linseed oil (52.67 $\%$ for fir and $52.59 \%$ for aspen) (Table 4 ). In samples impregnated with water repellents, the $W R E$ was the highest with styrene, followed by paraffin and linseed oil, respectively, compared to the untreated samples. After densification, the WRE decreased in the samples with paraffin and linseed oil treatment. On the other hand, depending on the compression rate and temperature, the WRE was significantly increased in the styrene-treated samples. After impregnation with styrene, the $W R E$ was found to be close to $100 \%$ in the wood samples (especially aspen) densified under $C 2$ conditions (Figure 3c).

With respect to densification conditions, the highest WRE average was obtained in undensified samples for fir wood $(54.55 \%)$ and in samples densified under $C 2$ conditions for aspen wood $(50.47 \%)$. The lowest $W R E$ average was determined in the samples densified under $B 1$ conditions for fir wood $(30.81 \%)$ and in the samples densified under $A 1$ conditions for aspen wood (37.17\%) (Table 4). According to Figure $3 \mathrm{c}$, the $W R E$ was found to be higher at the $20 \%$ compression rate in the paraffin-treated samples. However, the $W R E$ was higher in the linseed- and styrene-treated samples at the $40 \%$ compression rate. The WRE increased significantly depending on the compression rate, especially in the styrene-treated samples. On the other hand, while the effect of compression temperature on $W R E$ was insignificant in the paraffin- and linseed oiltreated samples, the WRE decreased in the styrene-treated samples due to a higher compression temperature.

\section{CONCLUSIONS}

\section{ZAKLJUČAK}

This study investigated the effect of pre-impregnation with water-repellent agents on dimensional stability and hygroscopicity in densified wood compressed at different rates and temperatures. Water re- pellents significantly influenced the physical properties of densified fir and aspen wood. In the densified samples, the $C R R$ and $T S$ values were generally reduced with impregnation pretreatments. More positive $C R R$ and $T S$ results were obtained from the linseed oil-treated samples than from those treated with paraffin. However, the most successful results were determined in the styrene-pretreated samples. The $C R R$ values of the styrene-treated fir and aspen woods decreased by $85 \%$ and $89 \%$, respectively, compared to the undensified (untreated) samples under the same conditions. In the same samples, the $T S$ values were decreased by 85 $\%$ and $91 \%$, respectively. Thus, the dimensional stability of the styrene pre-treated and densified samples was almost completely achieved depending on the compression conditions. These results can be shown as one of the most important outcomes of the study.

The $E M C$ and $W A$ were reduced in both wood species impregnated with water repellents. The $E M C$ and $W A$ were lower in the paraffin-treated samples than in the linseed oil-treated samples, while the lowest values for both wood species were found in the styrene-treated samples. In the densification process, due to the increased compression rate and temperature, the EMC and $W A$ were significantly reduced in the styrene-pretreated wood samples, whereas the WRE of the samples increased. After impregnation with styrene, the WRE was close to $100 \%$ in the wood samples (especially aspen) densified under $C 2$ conditions $\left(180{ }^{\circ} \mathrm{C} / 40 \%\right.$ ).

Regarding densification conditions, the most positive results on the physical properties of the wood samples were obtained at a high temperature $\left(180^{\circ} \mathrm{C}\right)$ and high compression rate (40\%). Due to the increased compression rate and temperature, the hygroscopicity was reduced and the dimensional stability increased in the fir and aspen samples.

\section{Acknowledgements - Zahvala}

The authors are grateful for the support of the Research Fund of Duzce University, Grant. No. BAP2017.07.01.522.

\section{REFERENCES}

\section{LITERATURA}

1. Baysal, E.; Sonmez, A.; Colak, M.; Toker, H., 2006: Amount of leachant and water absorption levels of wood treated with borates and water repellents. Bioresource Technology, 97 (18): 2271-2279. https://doi.org/10.1016/j.biortech.2005.10.044.

2. Baysal, E.; Yalinkilic, M. K.; Altinok, M.; Sonmez, A.; Peker, H.; Colak, M., 2007: Some physical, biological, mechanical, and fire properties of wood polymer composite (WPC) pretreated with boric acid and borax mixture. Construction and Building Materials, 21 (9): 18791885.

https://doi.org/10.1016/j.conbuildmat.2006.05.026.

3. Bekhta, P.; Proszyk, S.; Krystofiak, T.; Sedliacik, J.; Novak, I.; Mamonova, M., 2017: Effects of short-term thermomechanical densification on the structure and properties of wood veneers. Wood Material Science \& Engineering, 12 (1): 40-54.

https://doi.org/10.1080/17480272.2015.1009488. 
4. Budakci, M.; Pelit, H.; Sonmez, A.; Korkmaz, M., 2016: The effects of densification and heat post-treatment on hardness and morphological properties of wood materials. BioResources, 11 (3): 7822-7838.

https://doi.org/10.15376/biores.11.3.7822-7838.

5. Chao, W. Y.; Lee, A. W., 2003: Properties of southern pine wood impregnated with styrene. Holzforschung, 57 (3): 333-336. https://doi.org/10.1515/HF.2003.049.

6. Deka, M.; Saikia, C. N., 2000: Chemical modification of wood with thermosetting resin: effect on dimensional stability and strength property. Bioresource Technology, 73 (2): $179-181$.

https://doi.org/10.1016/S0960-8524(99)00167-4.

7. Dizman Tomak, E.; Yildiz, U. C., 2012: Applicability of vegetable oils as a wood preservative. Artvin Çoruh Üniversitesi Orman Fakültesi Dergisi, 13 (1): 142-157.

8. Dogu, D.; Tirak, K.; Candan, Z.; Unsal, O., 2010: Anatomical investigation of thermally compressed wood panels. BioResources, 5 (4): 2640-2663. https://doi.org/10.15376/biores.5.4.2640-2663.

9. Dubey, M. K.; Pang, S.; Chauhan, S.; Walker, J., 2016: Dimensional stability, fungal resistance and mechanical properties of radiata pine after combined thermo-mechanical compression and oil heat-treatment. Holzforschung, 70 (8): 793-800. https://doi.org/10.1515/hf-2015-0174.

10. Dwianto, W.; Inoue, M.; Norimoto, M., 1997: Fixation of compressive deformation of wood by heat treatment. Journal of the Japan Wood Research Society, 43 (4): 303-309.

11. Fang, C. H.; Mariotti, N.; Cloutier, A.; Koubaa, A.; Blanchet, P., 2012: Densification of wood veneers by compression combined with heat and steam. European Journal of Wood and Wood Products, 70 (1-3): 155-163. https://doi.org/10.1007/s00107-011-0524-4.

12. Garcia-Romeu, M. L.; Ciurana, J.; Ferrer, I., 2007: Springback determination of sheet metals in an air bending process based on an experimental work. Journal of Materials Processing Technology, 191 (1): 174-177. https://doi.org/10.1016/j.jmatprotec.2007.03.019.

13. Gong, M.; Lamason, C.; Li, L., 2010: Interactive effect of surface densification and post-heat-treatment on aspen wood. Journal of Materials Processing Technology, 210 (2): 293-296.

https://doi.org/10.1016/j.jmatprotec.2009.09.013.

14. Kamke, F. A., 2006: Densified radiata pine for structural composites. Maderas. Ciencia y tecnologia, 8 (2): 83-92. http://dx.doi.org/10.4067/S0718-221X2006000200002.

15. Kamke, F. A.; Sizemore, H., 2008: Viscoelastic thermal compression of wood. US Patent No. US7404422B2.

16. Kariz, M.; Kuzman, M. K.; Sernek, M.; Hughes, M.; Rautkari, L.; Kamke, F. A.; Kutnar, A., 2017: Influence of temperature of thermal treatment on surface densification of spruce. European Journal of Wood and Wood Products, 75 (1): 113-123. http://dx.doi.org/10.1007/s00107-016-1052-z.

17. Khalil, H. A.; Dungani, R.; Mohammed, I. A.; Hossain, M. S.; Aprilia, N. S.; Budiarso, E.; Rosamah, E., 2014: Determination of the combined effect of chemical modification and compression of agatis wood on the dimensional stability, termite resistance, and morphological structure. BioResources, 9 (4): 6614-6626. http://dx.doi.org/10.15376/biores.9.4.6614-6626.

18. Kocaefe, D.; Huang, X.; Kocaefe, Y., 2015: Dimensional stabilization of wood. Current Forestry Reports, 1 (3): 151-161. https://doi.org/10.1007/s4072.

19. Kollmann, F. F. P.; Kuenzi, E. W.; Stamm, A. J., 1975: Principles of Wood Science and Technology, vol. II, Wood Based Materials. Springer Berlin Heidelberg, New York.
20. Koski, A., 2008: Applicability of Crude Tall Oil for Wood Protection. Ph.D. dissertation, University of Oulu, Finland.

21. Kutnar, A.; Kamke, F. A., 2012: Influence of temperature and steam environment on set recovery of compressive deformation of wood. Wood Science and Technology, 46 (5): 953-964. https://doi.org/10.1007/s00226-011-0456-5.

22. Kutnar, A.; Kamke, F. A.; Sernek, M., 2008: The mechanical properties of densified VTC wood relevant for structural composites. Holz als Roh-und Werkstoff, 66 (6): 439446. https://doi.org/10.1007/s00107-008-0259-z.

23. Kwon, J. H.; Shin, R. H.; Ayrilmis, N.; Han, T. H., 2014: Properties of solid wood and laminated wood lumber manufactured by cold pressing and heat treatment. Materials \& Design (1980-2015), 62, 375-381.

https://doi.org/10.1016/j.matdes.2014.05.032.

24. Laine, K.; Rautkari, L.; Hughes, M.; Kutnar, A., 2013: Reducing the set-recovery of surface densified solid Scots pine wood by hydrothermal post-treatment. European Journal of Wood and Wood Products, 71 (1): 17-23. https://doi.org/10.1007/s00107-012-0647-2.

25. Lunguleasa, A.; Ayrilmis, N.; Spirchez, C.; Ozdemir, F., 2018: Investigation of the effects of heat treatment applied to beech plywood. Drvna industrija, 69 (4): 349355. https://doi.org/10.5552/drind.2018.1768.

26. Morsing, N., 2000: Densification of Wood - The Influence of Hygrothermal Treatment on Compression of Beech Perpendicular to the Grain, Ph.D. dissertation, Department of Structural Engineering and Materials, Technical University of Denmark, Lyngby, Denmark.

27. Nairn, J. A., 2006: Numerical simulations of transverse compression and densification in wood. Wood and Fiber Science, 38 (4): 576-591.

28. Navi, P.; Girardet, F., 2000: Effects of thermo-hydromechanical treatment on the structure and properties of wood. Holzforschung, 54 (3): 287-293. https://doi.org/10.1515/HF.2000.048.

29. Navi, P.; Heger, F., 2004: Combined densification and thermo-hydro-mechanical processing of wood. MRS Bulletin, 29 (5): 332-336. https://doi.org/10.1557/mrs2004.100.

30. Pelit, H.; Sonmez, A.; Budakci, M., 2014: Effects of ThermoWood $\AA$ process combined with thermo-mechanical densification on some physical properties of Scots pine (Pinus sylvestris L.). BioResources, 9 (3): 45524567. https://doi.org/10.15376/biores.9.3.4552-4567.

31. Pelit, H.; Budakci, M.; Sonmez, A., 2016: Effects of heat post-treatment on dimensional stability and water absorption behaviours of mechanically densified Uludağ fir and black poplar woods. BioResources, 11 (2): 3215-3229. https://doi.org/10.15376/biores.11.2.3215-3229.

32. Pelit, H.; Budakci, M.; Sonmez, A., 2018: Density and some mechanical properties of densified and heat posttreated Uludağ fir, linden and black poplar woods. European Journal of Wood and Wood Products, 76 (1): 79-87. https://doi.org/10.1007/s00107-017-1182-y.

33. Rowell, R. M., 2012: Handbook of wood chemistry and wood composites. CRC Press, Boca Raton.

34. Rowell, R. M.; Konkol, P., 1987: Treatments that enhance physical properties of wood. Gen. Tech. Rep. FPLGTR-55. Madison, WI: US Department of Agriculture, Forest Service, Forest Products Laboratory; $12 \mathrm{p}$.

35. Sandberg, D.; Haller, P.; Navi, P., 2013: Thermo-hydro and thermo-hydro-mechanical wood processing - An opportunity for future environmentally friendly wood products. Wood Material Science and Engineering, 8 (1): 64-88.

https://doi.org/10.1080/17480272.2012.751935. 
36. Sandberg, D.; Kutnar, A.; Mantanis, G., 2017: Wood modification technologies - A review. IForest, 10 (6): 895-908. https://doi.org/10.3832/ifor2380-010.

37. Seborg, R. M.; Tarkow, H.; Stamm, A. J., 1962: Modified woods. Forest Products Laboratory, Report No: 2192 (revised), Madison.

38. Stamm, A. J.; Tarkow, H., 1947: Dimensional stabilization of wood. J Phys Colloid Chem., 51 (2): 493-505.

39. Tabarsa, T.; Chui, Y. H., 1997: Effects of hot-pressing on properties of white spruce. Forest Products Journal, 47 (5): 71-76.

40. Welzbacher, C. R.; Rapp, A. O.; Haller, P.; Wehsener, J., 2005: Biological and mechanical properties of densified and thermally modified Norway spruce. In: Second European Conference on Wood Modification, Göttingen, Germany, 6-7 Oct. 2005.

41. Welzbacher, C. R.; Wehsener, J.; Rapp, A. O.; Haller, P., 2008: Thermo-mechanical densification combined with thermal modification of Norway spruce (Picea abies Karst) in industrial scale - Dimensional stability and durability aspects. Holz als Roh -und Werkstoff, 66 (1): 39 49. https://doi.org/10.1007/s00107-007-0198-0.

42. Williams, R. S.; Feist, W. C., 1999: Water repellents and water-repellent preservatives for wood. General technical report, F. P. L.; GTR-109, Madison.

43. Wolcott, M. P.; Kasal, B.; Kamke, F. A.; Dillard, D. A., 1989: Testing small wood specimens in transverse compression. Wood and Fiber Science, 21 (3): 320-329.

44. Yalinkilic, M. K.; Tsunoda, K.; Takahashi, M.; Gezer, E. D.; Dwianto, W.; Nemoto, H., 1998: Enhancement of biological and physical properties of wood by boric acid-vi- nyl monomer combination treatment. Holzforschung, 52 (6): 667-672. https://doi.org/10.1515/hfsg.1998.52.6.667.

45. *** 1976: ASTM D 1413-76. Standard test method of testing wood preservatives by laboratory soilblock cultures. Annual Book of ASTM Standard.

46. *** 2012: ISO 3129. Wood - Sampling methods and general requirements for physical and mechanical testing of small clear wood specimens. The International Organization for Standardization.

47. *** 2014: ISO 13061-1. Physical and mechanical properties of wood - Test methods for small clear wood specimens - Part 1: Determination of moisture content for physical and mechanical tests. The International Organization for Standardization.

48. *** 2017: ISO 13061-15. Physical and mechanical properties of wood - Test methods for small clear wood specimens - Part 15: Determination of radial and tangential swelling. The International Organization for Standardization.

\section{Corresponding address:}

Assoc. Prof. HUSEYIN PELIT, Ph.D.

Duzce University

Faculty of Technology

Department of Wood Products Industrial Engineering 81620 Duzce, TURKEY

e-mail: huseyinpelit@duzce.edu.tr 